AL IBTIDA: JURNAL PENDIDIKAN GURU MI (2019) Vol 6 (1): 110-123

DOI: http://dx.doi.org/ 10.24235/al.ibtida.snj.v6i1.3916

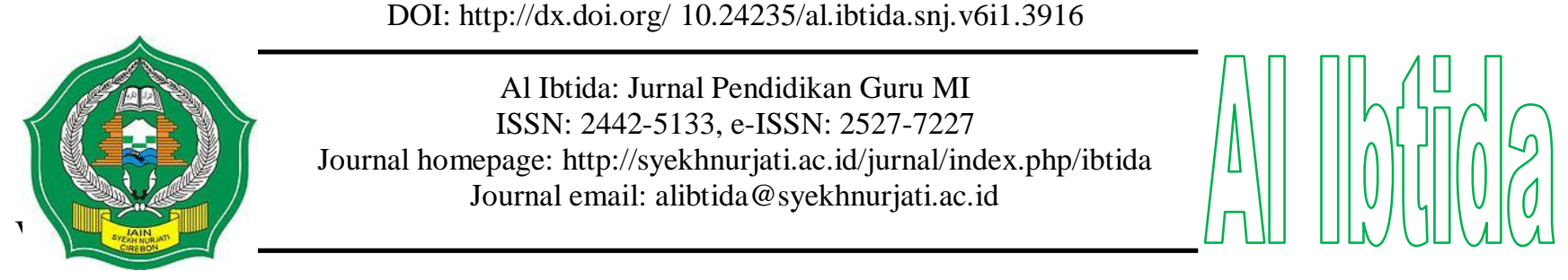

\title{
Problems in 2013 Curriculum Implementation for Classroom Teachers in Madrasah Ibtidaiyah
}

\author{
Muhamad Arif* \\ *Department of Madrasah Ibtidaiyah Teacher Education, \\ STAI Al-Azhar Menganti Gresik \\ Email : arif@ stai-alazharmenganti.ac.id \\ Sulistianah** \\ **Department of Madrasah Ibtidaiyah Teacher Education, \\ STAI Al-Azhar Menganti Gresik \\ Email : sulistianahsyamil@gmail.com
}

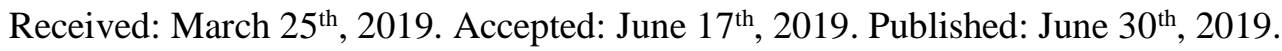

\begin{abstract}
2013 curriculum still becomes a problem which needs a solution as soon as possible so that the objectives of the 2013 curriculum can be achieved optimally. Starting from the facts above, encouraging researchers to conduct quite complex and in-depth research about contemporary problems experienced by classroom teachers in the application of the 2013 curriculum in the field and solutions for classroom teachers in facing the implementation problems of 2013 curriculum. In this study, researchers used qualitative methods using several data collection techniques, namely: observation, interviews, and documentation. Data sources in this study focused on classroom teachers. The data analysis technique uses Miles and Huberman. The findings from the research results are quite significant on the contemporary problem of the application of the 2013 curriculum, including 1) government problems, 2) institutional problems, 3) classroom teacher problems, 4) student personal problems, and 5) problems of understanding guardians. While, the solutions for classroom teachers in facing the implementation problems of 2013 curriculum, namely 1) the need for efforts from the government in improving teacher competence, 2) the establishment of cooperation with more competent institutions such as universities, and 3) the establishment of maximum communication between schools, students, and guardians of students with parenting frames. With these efforts, it is expected that the implementation problems of 2013 curriculum in the Islamic elementary school can be overcome.
\end{abstract}

Keyword: classroom teacher, implementation problems, 2013 curriculum. 


\begin{abstract}
Abstrak
Kurikulum 2013 masih menyimpan pekerjaan rumah dan perlu mendapatkan solusi secepat mungkin. Hal ini dilakukan agar tujuan dari penerapan kurikulum 2013 dapat tercapai secara maksimal. Berawal dari fakta di atas, memantik peneliti untuk melakukan penelitian yang cukup kompleks dan mendalam mengenai problemproblem kontemporer yang dialami guru kelas dalam penerapan kurikulum 2013 di sekolah, dan solusi guru kelas dalam menghadapi problem implementasi kurikulum 2013. Pada penelitian ini, peneliti menggunakan metode kualitatif dengan menggunakan beberapa teknik pengumpulan data, yaitu: observasi, wawancara, dan dokumentasi. Sumber data pada penelitian ini terfokus pada guru kelas. Teknik analisis data menggunakan Miles dan Huberman. Temuan dari hasil penelitian ini cukup signifikan, yaitu pada problem kontemporer penerapan kurikulum 2013, meliputi 1) problem pemerintah, 2) problem institusi, 3) problem guru kelas, 4) problem pribadi siswa, serta 5) problem pemahaman wali murid. Sementara itu, solusi guru kelas dalam menghadapi problem implementasi kurikulum 2013 yaitu: 1) diperlukannya upaya pemerintah dalam meningkatkan kompetensi guru, 2) terjalinnya kerjasama dengan instansi yang lebih kompeten seperti perguran tinggi, dan 3) terjalinnya komunikasi yang maksimal antara sekolah, siswa, dan wali murid dengan bingkai parenting. Dengan upaya-upaya tersebut, diharapkan problem penerapan kurikulum 2013 di madrasah ibtidaiyah dapat teratasi.
\end{abstract}

Kata kunci: guru kelas, masalah implementasi, kurikulum 2013.

\title{
INTRODUCTION
}

Republic of Indonesia Law No. 20 of 2003 concerning the national education system explains that education is the key to progress, the better the quality of education held by a society or nation, the better the quality of the community or nation will be followed. Education is a conscious and planned effort carried out by someone. In education, teachers are required to be able to create a fun learning environment and learning process so that students actively develop their potential.

Education cannot be separated from the curriculum. A curriculum actualization as the formation of competencies and character of students requires the activeness of a teacher in creating and growing various activities in accordance with the programmed plan. In this case, a teacher is required to be able to make decisions on the basis of an appropriate assessment when students have not been able to form basic competencies by redesigning more varied learning activities (Mulyasa, 2015).

The existence of the 2013 curriculum as a substitute for the 2006 Education Unit Level Curriculum in the world of education, especially in Primary School/Madrasah Ibtidaiyah (SD/MI) raises pros and cons. 2013 curriculum is more about integrated learning using themes to connect from one subject to another subject starting from Natural Sciences, Social Sciences, Bahasa Indonesia, Mathematics, and several other subjects, with the purpose to provide meaningful experiences to students . The existence of a theme is a main idea or main idea that becomes the main point in learning (Majid, 2014). 2013 curriculum is a new learning presenter 
in the world of education in Indonesia. Learning presented is oriented to the practices and needs of students in the hope that it can help create broad opportunities for students to see and build interrelated concepts so that students can have the ability to identify, collect, assess, and use information more meaningfully.

The above is a task that must be carried out by a teacher, so that the teacher can be successful if it is able to involve various components in the world of education, both principals, teachers, guardians of students and students. In addition, the teacher has the characteristics as a good information disseminator, because his main task is to convey information to students both inside and outside the classroom. The role of the teacher as a planner, executor, and assessment of learning, teachers are also required to have technical skills that enable them to organize standard material and manage it in learning and the formation of student competencies (Mulyasa, 2015).

Another thing a teacher must have in teaching is the ability to open and close learning instruction, provide reinforcement to students, and provide new colors in teaching and learning activities in the classroom (Saragih, 2008). In addition, Rios \& Manning (2015) says "Implications of this work for teacher educating that teacher educators must be a pedagogical imperative for research teacher education. They can actively change their teaching and engaging in action research so that teaching and research information is one that is not conceived as separate (or competing) endeavors. Besides, giving lessons is also doing research. This is a necessity in fulfilling the pedagogical aspects of the teacher. Teachers can actively change their teaching and engage in action research so that teaching and research are interrelated.

Similar to teachers in middle and upper education, primary school teachers also act as parents and informants to students both inside and outside the classroom. In addition, the teacher must be able to teach various subject matter. The class teacher is not only required to complete the lesson material that has been set, but the class teacher must master and appreciate in depth all the material taught to students. Therefore, in providing subject matter the teacher has a role and duty as manager of the teaching and learning process in the classroom with full demands for creativity. So, class teachers in basic education have absolute abilities in all subjects (Mulyasa, 2015).

The teacher's duties above must also be implemented in the 2013 curriculum, but the fact is not directly proportional to the conditions that occur in the field of primary school/Madrasah Ibtidaiyah (SD/MI). As happened in one of Madrasah Ibtidaiyah in Menganti Sub-district, Gresik Regency. MI Al-Azhar Menganti is a madrasah based on Islamic boarding school with accreditation A. The school has implemented the 2013 curriculum, since the instruction from the 
Ministry of Education and Culture. However, during the period of the 2013 curriculum in the madrasa, there were several obstacles felt by several parties. Based on the interview with Rizki Nugroho, classroom teacher of Class 3 A MI Al-Azhar Menganti, one of the problems felt by teachers is that teachers often experience doubts in the application of thematic learning while in class. Other problems faced were related to assessments, such as student's final semester assessment and the requirement for teachers to explain the different assessments of the 2013 curriculum appropriately to student guardians about the learning outcomes and development of the students.

The discussion on the implementation of the 2013 curriculum is found in several previous studies. The first study was carried out by Anwar (2014) on the basics of the implementation of the 2013 curriculum. From the research, it was explained that there are many challenges for the future, such as increasingly sophisticated, complex technology, and demand fast response to change. For this reason, the government as the mandate of the law has made curriculum changes from 2006 to the 2013 curriculum. In line with the development of the curriculum, teachers need to be developed, as Aslan's (2017) study of the challenges of education in the 21 st century presents the concept of "Pumping Teacher ". In this concept the teacher explained not only that it can provide motivation to children but can produce a generation of character according to the mandate of the 2013 curriculum.

The above is also a note from the results of the Kristiantari study (2015) which highlighted the analysis of the readiness of primary school teachers in implementing Integrative thematic learning in the 2013 curriculum very good but not supported in infrastructure in the implementation of the 2013 curriculum. Ahmad's (2013) problem in the implementation of the 2013 curriculum with the results of his research are: (1) a principal's instructional leadership can reduce the problems that occur in the 2013 curriculum implementation; (2) using instructional leaders because they have advantages, in addition to supervising and evaluating the curriculum, coordinating the curriculum and monitoring student progress in learning.

Moving on from a number of previous studies above, it appears that none explained in detail about the contemporary problems that occurred in the field in the process of applying the 2013 curriculum. This is in line with observational data in the field which showed that the implementation of the 2013 curriculum still kept sufficient homework to get a solution as soon as possible so that later it can achieve the objectives of the 2013 curriculum implementation to the fullest. Thus, researchers are interested in conducting quite complex and in-depth research. For this reason, this research is divided into two focus areas including: (1) Problems experienced by classroom teachers in the implementation of the 2013 curriculum in Madrasah Ibtidaiyah 
(Islamic Primary School) as well (2) Solutions for classroom teachers in dealing with the problems of the 2013 curriculum implementation in the field.

From the two focus of the above problems, the objectives of this study are: (1) to describe contemporary problems in the field experienced by Madrasah Ibtidaiyah classroom teachers, so that later can be an evaluation material from various parties, ranging from government, educational institutions, lecturers and teachers at the primary education level (Madrasah Ibtidaiyah), and (2) look for alternative solutions to the problems of 2013 curriculum implementation experienced by classroom teachers. Based on the above explanation, it is necessary to do this research.

\section{METHODS}

This research was conducted using qualitative methods because the problems discussed in this study were not related to numbers, but the problems would be revealed by describing, describing, and describing the problems of classroom teachers in the implementation of the 2013 curriculum at Madrasah Ibtidaiyah Al-Azhar Menganti Gresik and the solution offered by the classroom teacher as is. Basically qualitative research intends to understand the phenomenon of what is experienced by the subject of research naturally for example the problem of teacher class and action holistically and in a descriptive way in the form of words and scientific language (Moleong, 2011). This research was conducted at MI Al-Azhar Menganti Gresik, for 3 months, beginning in November 2018 - January 2019.

The data source in this study focused on class teachers from the class at MI Al-Azhar Menganti Gresik. Data collection techniques are in the form of: observation, interviews, and documentation. The first is through participatory observation, where the researcher observes the activities carried out by the resource person and the activities of the object (students). Observations were carried out by researchers by observing and recording how the learning process took place in MI Al-Azhar Menganti Gresik. Second, structured interviews because structured interviews can be prepared in such a way that the questions needed are only focused on reviewing the issues to be examined. This interview method is to find out the problem of class teachers in the implementation of the 2013 curriculum and the solutions offered by class teachers in MI Al-Azhar Menganti Gresik. Third, data collection uses documentation in the form of all documents that have relevance to this research.

After getting various data needed, the researcher analyzed the data using data analysis from Miles and Hubarman in (Arif, 2018b) who suggested that the activities in the qualitative data analysis were carried out continuously until complete, so the data was completely saturated. For that reason, the researcher uses 3 data analysis techniques, namely (1) data reduction which 
is reducing data which means summarizing, selecting the main things, focusing on the important things, looking for themes and patterns and removing unnecessary ones. So, the researcher's focus is only on data about class teacher problems in the implementation of the 2013 curriculum; (2) data display, which presents a set of information from the class teacher that has been arranged and allows for conclusions. Researchers need to display data on the grounds that the data obtained in qualitative research is in the form of narrative so that it requires simplification without reducing the content obtained; (3) Drawing and verifying the conclusion that is the interpretation of various things obtained by the researcher by noting patterns, explanations, currents of causes and propositions (Arif, 2018b). In this section the researcher expresses conclusions from the data that have been obtained during the researcher in the field, namely about the problem of the class teacher in the implementation of the 2013 curriculum and the solution.

\section{RESULTS AND DISCUSSION}

\section{Classroom Teacher' Problems in 2013 Curriculum Implementation}

The problems in the 2013 curriculum implementation by classroom teachers at MI AlAzhar Menganti varied, as interviewed by some classroom teachers, one of the interviews from Rizky Nugroho, a class IIIa teacher. Delivering about the problems in the implementation of the 2013 curriculum.

"Some of the problems we experience, as classroom teachers, cover several sectors, ranging from: Government problems, which provide basic education book material that is not all contextual and is too close to teacher learning, which makes the teacher not find comfort. Furthermore, the problem of class teachers, which is limited time in the application of the 2013 curriculum, and the inclusion of class 1-3 PJOK lessons, in our opinion, is less effective. Then the problem of parents who do not understand thematic learning. The next problem is from the Institution, which is the lack of debriefing related to the implementation of the 2013 curriculum to teachers and teachers so that it is not optimal in its application. And the problem of students is the difficulty in understanding material that is sometimes not contextual and mixed-up with the 2006 curriculum that uses an approach to subjects (Interview, Rizky Nugroho, December 3, 2018). "

The same thing was also conveyed by class IIb teachers, Yeni Dwi Mufarrocha reinforced the problems she experienced in the implementation of the 2013 curriculum.

The problem that we experienced in the implementation of the 2013 curriculum, was that the K-13 books distributed by the government were not timely, and tended to be late, which disrupted learning activities. Whereas the problem of the teacher is, lack of activity in responding to the development of the 2006 curriculum to the 2013 curriculum, so training needs to be further developed and able to understand the character of students and maximum classroom management. Furthermore the problem of the student guardian is the lack of understanding of the assessment of students, because it uses k-13 report cards that are very different from the first report card, both from the scale and description of student abilities (Interview, Yeni Dwi Mufarrocha, December 5 2018). 
The statement about the problems of class teachers in the implementation of the 2013 curriculum was also conveyed by Galuh Budi Hadaning as the Va class teacher, namely:

The problem from the government, is the lack of readiness of qualified facilities and infrastructure. For example the online report card discourse will be enacted massively, but to $\log$ in there are still many difficulties. The problem with the institution is only the adjustment of the system itself, which sometimes has not really matured has changed again, related to report card applications for example. Next is the class teacher because there are still difficulties in applying the many aspects of assessment in k-13. And the limitations of time in the field and the teaching and learning process were too offerable. Do we need more time? Because in the book K13 there is still a lot of material that is less profound, so it needs reinforcement from various learning sources, from videos and others, because if only glued from the book only a few are caught. Then on the parent's side is the difficulty in accompanying the learning process of students because of the change of learning approach to the theme (thematic) and so far in our opinion we have not found meaningful difficulties for the students, because they only have the flow. Just how we are a teacher must be able to understand students (Interview, Galuh Budi Hadaning, December 6, 2018).

A similar statement was also conveyed by Barudin, as the principal of MI Al-Azhar Menganti Gresik in the application of the 2013 curriculum.

According to us, the problem is still how the classroom teacher is, looking for the right solution. For the problem, it might be more technical, as in the student report cards that are too complicated, so sometimes we also feel sorry for the class teachers. Then the problem for class teachers, that is they have at least the desire to learn, about the development of the 2013 curriculum, and for students' problems is on theme-based learning, so sometimes students do not understand, as parents who have difficulty teaching individually at home, because there are differences in the 2013 curriculum and 2006 curriculum (Interview, Barudin, December 15, 2018).

From some of the results of the interview above, the researcher concluded that the problem of the implementation of the 2013 curriculum in MI Al-Azhar Menganti Gresik was divided into several parts, namely: (1) government problems related to the provision of material that tended to thematic, distribution subjects books that are not maximal since the 2013 curriculum, discourse on online report cards that still need a lot of improvement, and facilities and infrastructure that are still lacking for the provision of classroom teachers; (2) the problems of the institution are related to the lack of training and seminars intended for classroom teachers to support the understanding of classroom teachers in the 2013 curriculum; (3) the problems of class teachers are related to the lack of activity in responding to the development of the 2006 curriculum to the 2013 curriculum due to the lack of awareness of teachers in improving their competence; (4) problems in the form of the 2013 curriculum assessment, starting from UTS and PAS; (5) students' problems related to a little difficulty in understanding material that is sometimes not contextual and in the form of themes, and (6) problems from guardian students related to the lack of understanding of the 2013 curriculum. Guardians of students who become 
individual teachers when at home experience many obstacles in providing understanding to their children when thematic-based lessons, as well as the lack of understanding regarding student learning outcomes in the form of scoring in the form of a 2013 curriculum report card.

\section{Solutions for Classroom Teachers in Facing the Problem of the Implementation of 2013}

\section{Curriculum}

From the presentation of many problems faced by classroom teachers in the implementation of the 2013 curriculum, classroom teachers have several solutions to the problems that occur in MI Al-Azhar Menganti Gresik. As explained by Rizky Nugroho below:

So, the solution in our opinion, as a teacher in the field, is that the government should only provide the outline of the material as in the 2006 curriculum (KTSP). So that the development of materials and learning activities can be taken care of by the class teacher. While the solution for the institution is to provide a new curriculum, not only for class teachers but guardians of students. Being a class teacher, it is mandatory to further develop the principle of professionalism as a teacher, namely pedagogic competence, professional competence, social competence and personality competencies. With classroom teachers increasingly adding to their knowledge, the teacher will find solutions to various problems in learning. Maybe while we can say about the solution to the many problems in the implementation of the 2013 curriculum, this is limited. (Interview, Rizky Nugroho, December 3, 2018).

In line with the presentation from Rizky Nugroho, as a class IIb teacher Yeni, also explained about the solution of some of the obstacles encountered, are:

In our opinion, as class teachers who are directly confused with students and guardians of students, we hope that the government in publishing books can be initiated, so that later we will not be burdened and can study further so that learning can be maximized. If there is a delay, we must get a complaint from the student guardian, because they have already paid for the book. In addition, it is a solution for classroom teachers, so that they will continue to foster a spirit of re-learning, because the more knowledgeable people are more aware that they are still lacking, so study, study and study, because we will be able to answer various problems that occur in curriculum implementation. 2013. And problems from guardian students, maybe we give a re-understanding, when meeting taking report cards, or during special student guardian meetings (Interview, Yeni Dwi Mufarrocha, December 5, 2018).

The same thing was also conveyed by Galuh Budi Hadaning, as Classroom teacher of MI

Al-Azhar Menganti as it follows:

In dealing with the problems in the implementation of the 2013 curriculum, we as teachers must be wiser, such as about the discourse of online report cards, on the one hand we must follow the rules of the government, but on the other hand we are also required to add knowledge about these matters. For us as teachers, we use our time as much as possible, and our advice is that anyone who becomes a classroom teacher, we must really besides teaching, we also learn the lesson to the fullest. Like taking part in training, both about the development of learning models, the typical 2013 curriculum learning strategy, besides our madrasas, we also established cooperation with the campus, as a solution to the many problems in the 2013 curriculum, because on the STAI AlAzhar campus there are also some lecturers who are experts in development 2013 
curriculum because he was also a BAN madrasah assessor team, from here we learned a lot from him. For problems with student guardians, we as class teachers, sometimes need to provide special assignments that are typical of shared assignments, so the task can be done between students and parents. Maybe this is according to us and the solution to our madrasa (Interview, Galuh Budi Hadaning, December 6, 2018).

From the presentation of the class teacher above, Barudin as the principal also provided a solution, from the problem of the 2013 curriculum implementation.

We as principals provide several solutions in several issues related to curriculum change, such as for report cards, which are very different from the 2006 to 2013 curriculum, so how do the class teachers here, we collect together, to learn together, take and give. For the problem of training we still keep on scheduling, because of our problems, also from the speakers. Whereas the government program has not been maximized. So for this solution, we always support class teachers to keep abreast of developments, such as taking part in training and collaborating with lecturers at STAI Al-Azhar, so they can share knowledge from lecturers, because at STIA Al-Azhar also has a study program PGMI, and often conduct seminars and training. For guardians of students, we always provide an understanding of the 2013 curriculum through parenting, at each special occasion meeting of guardians of students, such as taking report cards, etc. (Interview, Barudin, December 15, 2018).

From the presentation of the results of the interview above, some conclusions can be drawn about the solutions of several problems in the implementation of the 2013 curriculum in MI al-Azhar Menganti Gresik, covering several parts, namely: Problems from the government, teachers giving suggestions, so that the implementation of the 2013 curriculum implementation, the government also oversees its development, such as the existence of material on thematic lessons and online report cards, which the government should review again. For institutional problems and class teachers, Madrasah Ibtidaiyah Al-Azhar Menganti have a significant new breakthrough, in addition to class teachers who are encouraged to attend training or seminars.

MI Al-Azhar Menganti Gresik also cooperates with a campus that is in the same shade as MI Al-Azhar, namely at the Al-Azhar Menganti Islamic College (STAI). This makes classroom teachers continue to study with education experts, both from BAN school / madrasah supervisors and assessors. To overcome the problems of students, namely with the teacher still updating their knowledge, so they can become the best servants for students. Meanwhile, to overcome the problems that come from guardian students, the solution is in the form of explanations in stages, such as at the time of taking report cards or at the meeting of guardians (parenting).

\section{Problems in the Implementation of 2013 Curriculum}

The implementation of the 2013 curriculum is an application of a new curriculum model in the world of education, especially in basic education. The desired actualization of the 2013 curriculum in learning is the formation of competencies and good character for students. 2013 curriculum requires teacher activeness in creating and growing various activities in accordance 
with the previously programmed plan. Teachers are required to be able to make decisions on the basis of appropriate judgments when students have not been able to form the desired basic competencies in each subject, learning activities can be stopped, changed or even repeated, as in the methods, models or learning strategies (Mulyasa, 2015).

The implementation of the 2013 curriculum is actually carried out in stages, so that schools are able to prepare education optimally, both in terms of teachers or even institutions. At the beginning of the 2013 curriculum implementation, the implementation was only applied to class students 1, 4, 7 and 10. As data from the Ministry of Education and Culture on the target of implementing the 2013 curriculum year after year:

Table 1: Stages of 2013 curriculum implementation

\begin{tabular}{ccc}
\hline Number & School year & $\begin{array}{c}\text { Target of 2013 curriculum } \\
\text { implementation schools }\end{array}$ \\
\hline 1 & $2015 / 2016$ & 12.691 \\
2 & $2016 / 2017$ & 52.878 \\
3 & $2017 / 2018$ & 126.907 \\
4 & $2018 / 2019$ & 198.821 \\
5 & $2019 / 2020$ & 211.512 \\
\hline
\end{tabular}

As an effort made by the Ministry of Education and Culture to reach the highest number in the 2019/2020 academic year, the government provides several programs that are qualified by qualified instructors, have high dedication and have the intention to help the government, especially in the world of education. Some of the efforts made are to equip teachers with 2013 curriculum training, starting from the paradigm and understanding of the contents of the 2013 curriculum (Syarifuddin, 2018). The 2013 curriculum has a different approach to the previous curriculum, namely using a scientific approach at all levels, from basic education to higher education. Therefore, preparing HR, namely a teacher, is absolutely necessary (Setiadi, 2016). As the results of Anwar's research, highlighted on several things the need to apply the 2013 curriculum, one of which is the age change factor that requires education stakeholders to develop education by implementing the 2013 curriculum (Anwar, 2014).

Maximum effort has been made by the Ministry of Education and Culture, but there are still some notes that need to be corrected. As the results of the study show, there is a problem experienced by classroom teachers, namely in the presentation of material from thematic books that tend to be fixed, this results in students being unable to understand the material in the form of themes. The same thing conveyed by Alawiyah (2013) which explained the existence of the 2013 curriculum resulted in teachers tending to be passive, less creative, because they were only oriented from the guidelines prepared by the government. In addition, the problem of class teachers is the lack of training and seminars on classroom teacher understanding in the 2013 
curriculum which resulted in a lack of active classroom teachers in responding to developments from the 2006 curriculum to the 2013 curriculum. The teacher's lack of awareness in improving competence. Even though increasing the competence of a teacher is the key to realizing quality education as the results of research by Sepriyanti (2012) and Cholifah (2017) which explain professional teachers have a role in realizing quality and high-competitiveness education in the future.

The implementation of the 2013 curriculum aims to encourage learning that is fun, effective, and meaningful as existing procedures, including: 1) Heating and apperception related to the teacher's initial ability to know the abilities of students and motivate students to know new things; 2) Exploration is a new learning activity and is associated with knowledge possessed by students; and 3) learning consolidation related to how a teacher is able to activate students in character building and connect with life experienced by students (Kusumawati \& Rulviana, 2017). This needs to be developed so that the objectives of the 2013 curriculum are to prepare humans to become Indonesian citizens who have faith, character, are productive, creative, innovative and affective, and can play a role in life, community, state in the development of world civilization (Albantani, 2015).

\section{Classroom Teacher Solutions in Facing 2013 Curriculum Implementation Problems}

The classroom teacher is a teacher who has a Diploma IV education or a Bachelor's degree in basic education. Class teachers have more intense assignments in the classroom, which are related to the relationship between teachers and students in the classroom. The success of a teacher depends on its ability to create a good learning atmosphere in the classroom, as well as being able to carry out its main tasks, namely by educating and teaching children to be able to master competencies that include, attitudes, knowledge and skills. Viewed from these responsibilities, classroom teachers have a more difficult task than subject teachers (Arif, 2018a).

Seeing the role of class teachers who are not easy in the learning process in the classroom, as well as many problems experienced by classroom teachers in implementing the 2013 curriculum implementation, a solution is needed so that learning can run optimally. First, the solution to the problem of the government, namely the teachers provide advice that in the implementation of the 2013 curriculum implementation, the government also oversees its development. This is in line with Tusriyanto's research (2016) that the need to provide activities to teachers in improving their competencies through workshops on curriculum development, syllabus, material, and others. In addition, the government must also guard the improvement of the teacher's mindset in improving competence (Slameto, 2014). 
Second, to overcome the problems of the institutions and classroom teachers, MI AlAzhar Menganti has a significant breakthrough. In addition to class teachers who are encouraged to take part in training or seminars, MI Al-Azhar Menganti also collaborate with campuses that are in the same shade as MI Al-Azhar Menganti, namely at Al-Azhar Menganti Islamic College (STAI). This makes classroom teachers continue to study with education experts, both from BAN school / madrasah supervisors and assessors. In line with the results of Aslan's research (2017) explaining the role of teachers in the 21st century, it is necessary to develop, one of which is offered is pumping teacher. The breakthrough was also supported by Ahmad's research (2014) which focused on the use of instructional leadership patterns, and Ghofur's research (2016) which provided a solution to the use of quantum teaching in improving teacher competence. Third, the solution that can be done to overcome the problems of students and guardians of students is to provide explanations in stages. This explanation can be given by the school to parents or guardians of students when taking report cards or meeting with guardians of students with parenting.

From the results of the discussion above, there are some differences between the results of previous studies and the facts that occurred in the field. The results of previous studies are more specific in highlighting the problems experienced by classroom teachers, whereas in the fact that occurs in the field, the problem is not only compartmentalized with the government, but in essence all parties have problems in the implementation of the 2013 curriculum. , arrived at the student guardian. The solutions offered by this study include establishing cooperation in improving the professional competence of classroom teachers with universities and implementing parenting on student guardians in an effort to understand the 2013 curriculum.

\section{CONCLUSION}

Conclusions from the results of this study are the problems in the implementation of the 2013 curriculum which are divided into five parts: 1) problems from the government, 2) problems from institutions, 3) problems from classroom teachers, 4) problems from students 5) problems from guardian students. So, basically education is not only about the responsibility of the government, or merely an institution. But the success of education is a shared responsibility and all parties are interrelated in an effort to improve education in Indonesia. Meanwhile for the solutions offered by this study, including: 1) the need for increased coordination between teachers and the government in an effort to improve teacher competence; 2) institutions and class teachers are required to have a breakthrough in improving competence, not just waiting for orders from the center, but how to take solutions that do not conflict with applicable rules, one of them is by collaborating with universities as an effort to improve teacher competence and keep 
up with curriculum development. 3) As well as carrying out meetings with parenting (parenting) is the matter of delivering curriculum development appropriately. This is done in an effort to avoid misunderstandings between the school, students and guardians of the student.

\section{REFERENCES}

Ahmad, S. (2014). Problematika Kurikulum 2013 dan Kepemimpinan Instruksional Kepala Sekolah. Jurnal Pencerahan, 8(2).

Alawiyah, F. (2013). Peran Guru dalam Kurikulum 2013. Jurnal Aspirasi, 4(1), 65-74.

Albantani, A. M. (2015). Implementasi Kurikulum 2013 Pada Pembelajaran Bahasa Arab di Madrasah Ibtidaiyah. Arabiyat: Jurnal Pendidikan Bahasa Arab dan Kebahasaaraban, 2(2). https://doi.org/10.15408/a.v2i2.2127.

Anwar, R. (2014). Hal-Hal yang Mendasari Penerapan Kurikulum 2013. Humaniora, 5(1), 97. https://doi.org/10.21512/humaniora.v5i1.2987.

Arif, M. (2018a). Peningkatan kompetensi pedagogik dan profesional guru kelas Madrasah Ibtidaiyah di Kabupaten Gresik: studi multi kasus di Madrasah Ibtidaiyah Plus Riyadlatul Athfal Hulaan Menganti dan Madrasah Ibtidaiyah Mamba'us Sholihin Suci Manyar (PhD Thesis). UIN Sunan Ampel Surabaya.

Arif, M. (2018b). Revitalisasi Pendidikan Cinta Tanah Air di Pondok Pesantren Darul Ihsan Menganti Gresik. Jurnal Iqra': Kajian Ilmu Pendidikan, 3(2), 277-296. https://doi.org/https://doi.org/10.25217/ji.v3i2.369.

Aslan, A. (2017). Pumping Teacher dalam Tantangan Pendidikan Abad 21. Mulallimuna, 02(02), 89-100.

Cholifah, P. S. (2017). Profesionalisme Guru Sekolah Dasar: Membangun Komunitas Belajar Profesional Melalui Blended Learning. Ar-Risalah, 15(01), 1-13.

Ghofur, M. A. (2016). Pelaksanaan Quantum Teaching untuk Meningkatkan Kompetensi Pedagogik Guru Sekolah Dasar. PEDAGOGIA: Jurnal Pendidikan, 5(2), 255-266.

Kusumawati, N., \& Rulviana, V. (2017). Pengembangan Kurikulum di Sekolah Dasar. Magetan: Media Grafika.

Majid, A. (2014). Pembelajaran Tematik Terpadu. Bandung: Remaja Rosdakarya.

Mulyasa, E. (2015). Pengembangan dan Implementasi Kurikulum 2013. Bandung: Remaja Rosdakarya.

Ríos, C.D.L. \& Manning, M. S. (2015). ARTICLE WITHDRAWN: Teacher Educators as Cultural Workers: Problematizing Teacher Education Pedagogies. Studying Teacher Education, 11(3), 272-293. https://doi.org/10.1080/17425964.2015.1065806.

Saragih, A. H. (2008). Kompetensi minimal seorang guru dalam mengajar. Jurnal Tabularasa, 5(1), 23-34.

Sepriyanti, N. (2012). Guru Profesional adalah kunci mewujudkan Pendidikan Berkualitas. AlTa Lim Journal, 19(1), 66-73.

Setiadi, H. (2016). Pelaksanaan Penilaian Pada Kurikulum 2013. Jurnal Penelitian dan Evaluasi Pendidikan, 20(2), 166. https://doi.org/10.21831/pep.v20i2.7173 
Slameto, S. (2014). Permasalahan-Permasalahan Terkait Dengan Profesi Guru Sd. Scholaria: Jurnal Pendidikan Dan Kebudayaan, 4(3), 1-12.

Sugiyono. (2010). Metode Penelitian Pendidikan Pendekatan Kuantitatif, Kualitatif dan R\&D. Bandung: Alfabeta.

Syarifuddin, K. (2018). Inovasi Baru Kurikulum 2013 Pendidikan Agama Islam dan Budi Pekerti. Yogyakarta: Budi Utama.

Tusriyanto, T. (2016). Pengaruh Program Peningkatan Kualifikasi Akademik S-1 Terhadap Kompetensi Pedagogik Dan Profesional Guru Mi Se-Provinsi Lampung. TAPIS: Jurnal Penelitian Ilmiah, 16(1), 53-74. 